\title{
LESI SERVIX PADA WANITA USIA SUBUR DALAM PEMERIKSAAN INSPEKSI VISUAL ASAM ASETAT
}

\author{
Bambang Sarwono \\ Email : bambangsmgl@gmail.com
}

\begin{abstract}
Screening IVA inspection helpful to know that there are lesions on the cervix. The incidence of cervical cancer in Wonosobo $1.1 \%$ higher than the incidence in Central Java province and $1.5 \%$ higher than the incidence of cervical cancer in Indonesia.

This research method using cross sectional analytic method correlational retrospective approach and supported by qualitative. Samples of all women of childbearing age who check the cervix with IVA method in Wonosobo district health center in 2013, as many as 1710 people The results of the bivariate statistical analysis using chi square $p$ value $=0.043$ with $\mathrm{RP}=1,638(\mathrm{Cl} 95 \%$ to the value range $1023-2622)$. This means that there is a significant relationship between history kaknker in families with positive VIA test results.

Cancer family history is a risk factor for cervical lesions WUS in Wonosobo regency. Conclusions history of cancer in families at risk of cervical lesions occur 1,831 times compared WUS patients with no history of cancer in the family. WUS age and the age of first sexual activity is a risk factor protective whereby $95 \%$ confidence interval for the number one in women of reproductive age .
\end{abstract}

Keyword : Cervical Lession, IVA

Magister Program in epidemiology Diponegoro University

Lesi displasia merupakan awal terjadinya kanker servik. Kanker serviks adalah salah satu jenis keganasan atau neoplasma yang terjadi di daerah leher rahim (serviks) dan atau mulut rahim, yang merupakan bagian terendah dari rahim yang menonjol ke punkankerk liang sanggama (vagina). ${ }^{1-3}$

Diperkirakan insiden penyakit ini adalah sekitar 100 per 100.000 penduduk. Setiap tahun tidak kurang dari 15.000 kasus kanker serviks terjadi di Indonesia. Itu membuat kanker serviks disebut sebagai penyakit pembunuh wanita nomor $1 \mathrm{di}$ Indonesia. ${ }^{4}$
Kanker serviks atau dikenal dengan kanker leher rahim yang terjadi di Wonosobo dipengaruhi oleh berbagai faktor yang saling berinteraksi sebagai tritunggal dalam epidemiologi yaitu pejamu (Host), agent dan lingkungan (Environment).

Kunci keberhasilan program pengendalian kanker leher rahim adalah penapisan (screening) yang diikuti dengan pengobatan yang adekuat. Deteksi dini kanker serviks meliputi program skrining yang terorganisasi dengan target pada kelompok usia yang tepat dan sistem rujukan yang efektif di semua tingkat pelayanan kesehatan. Metode skrining 
yang dapat digunakan adalah Inspeksi Visual dengan Aplikasi Asam Asetat (IVA). ${ }^{5}$ Skrining melalui pemeriksaan IVA bermanfaat untuk mengetahui lesi yang ada pada servik. Dengan adanya program metode skrining yang lebih sederhana dan relatif memerlukan biaya yang murah dan praktis yaitu dengan metode IVA, kiranya dapat menjangkau lebih banyak masyarakat ekonomi golongan menengah ke bawah. ${ }^{5-8}$

Kabupaten Wonosobo adalah salah satu daerah pengahasil tembakau di Jawa Tengah, data pertanian pada tahun 2011 produksi meningkat sampai dengan $56,69 \% .^{9}$ Studi awal pemeriksaan deteksi dini kanker leher rahim di Kabupaten Wonosobo pada tahun 2009 menunjukkan bahwa dari 9702 yang diperiksa 321 positif mengalami pra kanker servik $(3,31 \%)$, tahun 2010 dari 2620 yang diperiksa 127 positif mengalami pra kanker servik(4,85\%), tahun 2012 dari 207 yang diperiksa 6 positif mengalami pra kanker servik(2.9\%), dan pada tahun 2013 dari 2010 yang diperiksa 46 positif mengalami pra kanker servik $(2,3 \%) .^{10}$

Menurut Pusat Data dan Informasi Kementrian Kesehatan Republik Indonesia tahun 2014 ,tahun 2013 Kanker cervik merupakan penyakit kanker terbesar di Indonesia 0.8\% dibanding Kanker mamae $0.5 \%$. Propinsi Jawa Tengah tahun 2013 kejadian Kanker cervik sebanyak 1.2\% dibanding Kanker mamae 0.7\%. ${ }^{11}$ Data dari Dinas Kesehatan Provinsi Jawa Tengah tahun 2014 kejadian Kanker cervik di Kabupaten Wonosobo tahun 2013 sebesar 2.3\% kejadian Kanker cervik di Kabupaten Wonosobo 1.1\% lebih tinggi dari kejadian kanker cervik yang ada di Propinsi Jawa Tengah. ${ }^{12}$
Menurut Pusat Data dan Informasi Kementrian Kesehatan Republik Indonesia tahun 2014 kejadian Kanker cervik tahun 2013 pada usia 1-5 tahun $0.1 \%$, usia $6-14$ tahun $0.1 \%$, usia $15-$ 24 tahun sebesar $0.6 \%$, usia $25-34$ tahun $0.9 \%$, usia $35-44$ tahun $2.1 \%$ dan usia $45-54$ tahun $3.5 \%$ dari data tersebut terjadi prevalensi peningkatan kejadian Kanker cervik yang cukup tinggi pada kelompok usia subur dibanding pada usia anak dan remaja. ${ }^{11}$

Kanker cervik merupakan penyakit kanker dengan prevalensi tertinggi di Indonesia kejadian Kanker cervik di Kabupaten Wonosobo 1.1\% lebih tinggi dari kejadian di Provinsi Jawa Tengah dan $1.5 \%$ lebih tinggi dari kejadian Kanker cervik di Indonesia. Angka kejadian Kanker cervik terus meningkat pada kelompok wanita usia subur (WUS) dibandingkan anak dan remaja.

Diperlukan strategi penanganan Kanker cervik dengan melakukan deteksi kanker dini dengan menggunakan inspeksi visual asam acetat (IVA) Sebagaimana belum diketahuinya pengaruh faktor-faktor risiko lesi servik seperti faktor pejamu; jumlah paritas, usia memulai aktifitas seksual, usia pertama mengalami menstruasi dan faktor eksogen; perokok aktif maupun pasif serta penggunaan kontrasepsi hormonal jangka panjang pada wanita usia subur di Kabupaten Wonosobo maka perlu dilakukan penelitian

\section{METODE PENELITIAN}

Desain penelitian ini dilakukan dengan menggunakan cross sectional dengan metode analitik korelasional dengan pendekatan retrospective dan ditunjang dengan kualitatif. Penelitian 
ini bertujuan untuk menilai hubungan antara dua variabel bebas faktor risiko lesi servik dengan kejadian lesi servik. Populasi dalam penelitian ini sejumlah 2010 orang wanita usia subur yang memeriksakan servik dengan metode inpeksi visual asam asetat (IVA) sedangkan populasi Terjangkau dalam penelitian ini adalah 1575 orang wanita usia subur yang memeriksakan servik dengan metode IVA. Sampel dalam penelitian ini adalah semua wanita usia subur yang memeriksakan servik dengan metode IVA yang terkankertat di Puskesmas Kabupaten Wonosobo pada tahun 2013, sebanyak 1710 orang

Metode pengumpulan data menggunakan data sekunder dari kankertatan medik pemeriksaan IVA dan data primer diperoleh dari indepth interview pasien yang melakukan pemeriksaan IVA data berupa ceklist yang diperoleh dari 7 Puskesmas di Kabupaten Wonosobo tahun 2013 yang telah melakukan pemeriksaan IVA.

Analisis data univariat menggunakan distribusi frekwensi 13 Analisis bivariat (Uji Hipotesis) Chi square, disajikan dengan crosstabulation dengan menggunakan $\alpha=0,05$ dan $\mathrm{Cl} 95 \%$. risiko dihitung dengan menggunakan Rasio Prevalen (RP). Cl $95 \%$ sedangkan analisa multivariate yang digunakan adalah regresi logistic ganda dengan melihat od rasio (OR) pada variabel bebas yang mempunyai signifikansi $<0,25$. dengan dependent dengan $\mathrm{p}$ value > 0,05

\section{HASIL PENELITIAN}

Hubungan test IVA dengan riwayat kanker keluarga WUS yang melakukan pemeriksaan lesi servik di Kabupaten Wonosobo Tahun 2013 proporsi pada kelompok WUS dengan riwayat kanker keluarga dengan hasil test IVA positif sebesar $11.8 \%$, nilai ini lebih rendah jika dibandingkan dengan hasil test IVA negative pada kelompok WUS yang tidak ada riwayat kanker pada keluarga sebesar $88,2 \%$. Sedangkan prosentase hasil test IVA negative pada kelompok WUS yang mempunyai riwayat kanker pada keluarga sebesar $7,1 \%$ jauh lebih rendah bila dibandingkan dengan kelompok WUS yang tidak mempunyai riwayat kanker pada keluarga dengan hasil test IVA negative sebesar 92.9\%. Adapun berdasarkan hasil analisis statistik bivariat dengan menggunakan chi square didapatkan nilai $p=0,043$ dengan $\mathrm{RP}=1.638(\mathrm{Cl} 95 \%$ dengan rentang nilai $1.023-2.622)$. Artinya ada hubungan yang bermakna antara riwayat kaknker pada keluarga dengan hasil test IVA positif. Jadi adanya riwayat kaker pada keluarga merupakan faktor risiko terjadinya lesi servik pada WUS di Kabupaten Wonosobo.

Hubungan test IVA dengan pemakaian KB hormonal WUS yang melakukan pemeriksaan lesi servik di Kabupaten Wonosobo tahun 2013, proporsi penggunaan alat kontrasepsi dimana WUS yang tidak menggunakan atau menggunakan KB hormonal dari 5 tahun dengan hasil test IVA positif sebesar $23,6 \%$, nilai ini lebih rendah jika dibandingkan dengan hasil test IVA positif dengan pada kelompok WUS yang tidak menggunakan atau menggunakan KB hormonal kurang dari 5 tahun sebesar 76,4\%. Sedangkan proporsi WUS yang menggunakan KB hormonal lebih dari 5 tahun dengan IVA negative sebesar 
$32,1 \%$ lebih rendah bila dibandingkan dengan kelompok WUS yang tidak menggunakan atau menggunakan KB hormonal kurang dari 5 tahun dengan test IVA negatif $67,9 \%$. Adapun berdasarkan hasil analisis statistik bivariat dengan menggunakan chi square didapatkan nilai $p=0,037$ dengan $\mathrm{RP}=0,678(\mathrm{Cl} 95 \%$ dengan rentang nilai $(0.469-0.982)$. Artinya ada hubungan yang bermakna antara penggunaan KB hormonal lebih dari 5 tahun dengan hasil test IVA positif. Jadi adanya penggunaan KB hormonal lebih dari 5 tahun merupakan faktor risiko protektif terjadinya lesi servik pada WUS di Kabupaten Wonosobo.variabel umur WUS, umur menstruasi I, usia memulai aktifitas sex

Riwayat Kanker Keluarga Berdasarkan uji Wald $=4,656$, RP $=$ 1.831, nilai $p=0,031<0.05$ dengan $95 \% \mathrm{Cl}=1,057-3,173$ artinya WUS yang mempunyai keluarga dengan riwayat kanker dimungkinkan berisiko 1,831 kali mengalami lesi servik (dysplasia) bila dibandingkan dengan WUS yang tidak ditemukan riwayat kanker.

Umur WUS Berdasarkan uji Wald $=$ $6,251 \mathrm{RP}=0,503$ nilai $\mathrm{p}=0.012<$ 0,05 dengan $95 \% \mathrm{Cl}=0,294-0.862$ artinya walaupun ada hubungan antara umur WUS dengan kejadian lesi servik namun hubungan ini bersifat protektif. Usia Memulai Aktifitas Sex pertamakali Berdasarkan uji Wald $=6,482$, RP $=$ 0.440 nilai $p=0,011<0,05$ dengan $95 \% \mathrm{Cl}=0,234-0,828$ artinya WUS yang memulai aktifitas sex I kurang dari 17 tahun mempunyai hubungan dengan kejadian lesi walaupun bersifat protektif.

\section{PEMBAHASAN}

pertamakali, riwayat kanker keluarga dan riwayat penggunaan KB hormonal akan diuji dengan menggunakan analisis multivariat karena nilai $\mathrm{p}<$ 0,25 .

Analisa multivariate dalam enelitian ini terdapat 3 (tiga) variabel yang merupakan keseluruhan dari jumlah variabel yang diteliti, yang diduga berpengaruh dalam Lesi servik di Kabupaten Wonosobo dengan nilai $\mathrm{p}<$ 0,25 .

Setelah dilakukan penapisan dari bebagai variabel yang dominan dengan menggunakan metode statistik logistik ganda antara variabel independent dengan variabel dependent ternyata tinggal 3 variabel yang bermakna yakni riwayat kanker pada keluarga, Umur WUS dan umur aktifitas seks pertama.

Faktor risiko yang terbukti berhubungan kanker analisis multivariat terjadinya lesi servik di Kabupaten Wonosobo.

Riwayat kanker pada keluarga dalam penelitian ini menunjukkan bahwa dengan riwayat kanker pada keluarga dimungkinkan WUS dimungkinkan berisiko mengalami lesi servik sebesar 1,831 kali dari pada WUS yang tidak mempunyai riwayat kanker pada keluarga, dengan $\mathrm{RP}=$ 1,831 , nilai $p=0,031<0,05$ dengan $95 \% \mathrm{Cl}=1.057-3.173$.

Adanya riwayat kanker yang ditemukan pada keluarga merupakan faktor penting terjadinya lesi servik yang merupakan awal terjadinya kanker servik. Menurut Noralane M. Lindor dan Mark H. Greene bahwa mutasi genetik atau hilangnya fungsi normal dari gen adalah penyebab kanker. ${ }^{14}$ Dua jenis gen yang penting adalah gen pemicu kanker (onkogen) dan gen peredam kanker (tumor 
suppressor gene). Onkogen sendiri terjadi akibat termutasinya gen protoonkogen yang fungsi asalnya adalah pengaturan perbanyakan sel. Mutasi gen proto-onkogen merubah jatidirinya menjadi onkogen yang memicu perbanyakan sel tanpa kendali. ${ }^{14}$

Di sisi lain, gen penekan tumor sebagaimana namanya memang berfungsi untuk memastikan tidak adanya kanker dalam tubuh. namun mutasi atau penghilangan fungsi gen ini akan menyebabkan tubuh rentan terhadap tercetusnya kanker ${ }^{14-15}$ Peutz-Jeghers Syndrome (PJS) diduga terkait dengan kanker payudara (bilateral dilaporkan), kanker serviks, jinak dan ganas tumor ovarium (terutama kanker sel granulosa), kanker testis, dan kanker pankreas. ${ }^{16}$ Gen dan kromosom lokasi: Sebuah gen kinase serin treonin, STK11, di 19p13.3. Mutasi ditemukan di lima keluarga Peutz-Jeghers Syndrome atau individu, termasuk penghapusan, tiga mutasi nonsense, dan satu akseptor situs sambatan mutasi. ${ }^{16}$

Dalam penelitian yang dilakukan oleh Nagy Rebeckanker, Kevin Sweet dan Charis En menyampaikan bahwa Sekitar 5-10\% dari semua kanker yang diwariskan, mayoritas kanker autosomal dominan dengan penetrasi yang tidak lengkap. Sementara sebagian kecil dari beban kanker kanker keseluruhan di seluruh dunia, penemuan genetik molekuler yang telah dihasilkan dari studi keluarga dengan kanker diwariskan tidak hanya mengubah kankerra memberi masukan keluarga dan mengelola, tetapi menjelaskan jalur regulasi molekul penting dalam penanganan tumor. ${ }^{17}$

Hal ini juga sesuai dengan indepth interview yang dilakukan pada saat penelitian
"Di keluarga saya memang ada yang pernah menjalani operasi untuk kanker beberapa tahun yang lalu di RSUD Wonosobo dan sekarang sudah dinyatakan sembuh.

Pendapat dari responden lain " dari tiga bersaudara kakak tertua saya memang pernah mengalami kanker, tetapi kanker servik dan sudah diobati ke beberapa rumah sakit namun hasilnya belum ada"

Umur WUS yang lebih dari 45 Berdasarkan uji Wald $=6,251 \mathrm{RP}=$ 0.503 nilai $p=0.012<0,05$ artinya walaupun ada hubungan antara umur WUS dengan kejadian lesi servik, namun menimbang rentang nilai 95\% interval keperkankeryaan 0.339 0.945, faktor Umur WUS lebih dari 45 tahun masih melingkupi angka 1 maka faktor ini sebagai faktor protektif terhadap terjadinya lesi servik.

Hasil analisa bivariat antara umur dengan kejadian lesi servik terlihat bahwa hasil test IVA positif pada kelompok usia lebih dari 45 tahun lebih sedikit bila dibandingkan dengan kelompok usia kurang dari atau sama dengan 45 tahun, demikian juga sebaliknya bila dilihat hasil test IVA negative pada kelompok usia lebih dari 45 tahun lebih besar daripada kelompok usia kurang dari atau sama dengan 45 tahun.

Normal "ectocervix" (bagian dari uterus memperluas ke dalam vagina) yang sehat berwarna merah muda dan ditutupi sel tipis yang disebut sel skuamosa. The "endoserviks" atau saluran serviks terdiri dari jenis lain dari sel yang disebut sel kolumnar. Wilayah di mana sel-sel ini bertemu disebut "zona transformasi" (T-zone) dan yang paling mungkin lokasi untuk sel-sel abnormal atau prakanker untuk berkembang. ${ }^{18}$ 
Usia fisiologis serviks yaitu, penuaan terkait atrofi lapisan epitel, "migrasi" dari zona transformasi serviks dan squamocolumnar junction, batas distal dari zona transformasi serviks, ke kanal serviks akibat penuaan dapat mempengaruhi prevalensi jenis HPV. ${ }^{19}$

Semakin tua usia seseorang, maka semakin meningkat risiko terjadinya kanker laher rahim. Meningkatnya risiko kanker leher rahim pada usia lanjut merupakan gabungan dari meningkatnya dan bertambah lamanya waktu pemaparan terhadap karsinogen serta makin melemahnya sistem kekebalan tubuh akibat usia.

Disamping jumlah test IVA positif kelompok umur ditas 45 tahun lebih sedikit dibanding kelompok lainya, rata rata umur sampel adalah 37,63 tahun. Disini dapat diasumsikan bahwa wanita yang memeriksakan IVA pada tahun tersebut relative masih muda.

Sejalan dengan penelitian oleh Jean Damascène Makuza tentang Prevalensi dan faktor risiko untuk kanker serviks dan pra-kanker lesi di Rwanda didapatkan hasil bahwa umur tua lebih dari 40 tahun terjadi penurunan risiko $(\mathrm{OR}=0,52 ; 95 \% \mathrm{Cl}=$ 0,28-0,97). ${ }^{20}$

Hasil penelitian ini berbeda dengan penelitian yang dilakukan oleh Alejandra Kankerstañón, dalam penelitian skrening terhadap wanita pada kelompok umur 50-64 tahun, 6569 tahun dan kelompok diatas 70 tahun, dimana pada kelompok umur 65-69 tahun resiko kanker 2,4 kali lebih tinggi dibanding pada kelompok umur 50-64 tahun dan resiko tersebut menurun lagi pada kelompok ketiga. ${ }^{21}$

Usai memulai aktifitas sex kurang dari 17 tahun Berdasarkan uji $W$ ald $=6,482, \quad R P=0.440$ nilai $p=$
$0,011<0,05$ dengan $95 \% \mathrm{Cl}=0.234-$ 0.828 artinya artinya walaupun ada hubungan antara Usai memulai aktifitas sex kurang dari 17 tahun dengan kejadian lesi servik, namun menimbang rentang nilai $\mathrm{Cl}$ 95\% interval keperkankeryaan 0.236 0.836, faktor Umur WUS dalam melakukan aktifitas sex I masih melingkupi angka 1 maka faktor ini disimpulkan sebagai faktor protektif terhadap terjadinya lesi servik.

Mekanisme yang pengalaman awal hubungan seksual pertama dan kehamilan pertama dapat mempengaruhi risiko karsinogenesis serviks dapat dijelaskan oleh pengaruh hormonal steroid pada infeksi HPV dan respon imun host untuk HPV selama pra-remaja dan remaja. Zona transformasi dari epitel serviks telah diakui sebagai tempat di mana infeksi HPV cenderung menyebabkan kanker, dan kerentanan daerah ini diyakini terkait dengan penipisan dari epitel berlapis, sehingga memfasilitasi paparan dari lapisan basal untuk HPV dengan trauma minimal. Ketidak dewasaan biologis selama masa remaja juga telah diyakini sebagai faktor kerentanan tambahan. ${ }^{22-24}$ Selama masa remaja dan kehamilan, serviks terkena tingkat ditambah perubahan hormonal. ${ }^{24}$

Hubungan seks idealnya dilakukan setelah seorang wanita benar-benar matang. Ukuran kematangan bukan hanya dilihat dari sudah menstruasi atau belum. Kematangan juga bergantung pada sel-sel mukosa yang terdapat di selaput kulit bagian dalam rongga tubuh. ${ }^{25}$ Umumnya sel-sel mukosa baru matang setelah wanita berusia 20 tahun ke atas. Jadi, seorang wanita yang menjalin hubungan seks pada usia remaja, 
paling rawan bila dilakukan di bawah usia 16 tahun. Hal ini berkaitan dengan kematangan sel-sel mukosa pada serviks. Pada usia muda, sel-sel mukosa pada serviks belum matang. ${ }^{26}$ Artinya, masih rentan terhadap rangsangan sehingga tidak siap menerima rangsangan dari luar termasuk zat-zat kimia yang dibawa sperma. Karena masih rentan, sel-sel mukosa bisa berubah sifat menjadi kanker. Sifat sel kanker selalu berubah setiap saat yaitu mati dan tumbuh lagi. Dengan adanya rangsangan, sel bisa tumbuh lebih banyak dari sel yang mati, sehingga perubahannya tidak seimbang lagi. Kelebihan sel ini akhirnya bisa berubah sifat menjadi sel kanker. Lain halnya bila hubungan seks dilakukan pada usia di atas 20 tahun, sel-sel mukosa tidak lagi terlalu rentan terhadap perubahan. ${ }^{26-27}$

Hasil uji bivariat antara usia memulai aktifitas sex yang pertama dengan kejadian lesi servik dapat diketahui bahwa hasil test IVA pada kelompok aktifitas sex kurang dari 17 tahun jauh lebih kecil dibanding dengan kelompok yang melakukan aktifitas sex lebih dari atau sama dengan 17 tahun, demikian juga pada kelompok dengan hasil test IVA negative kelompok dengan aktifitas sex kurang dari 17 tahun lebih kecil dibanding dengan kelompok yang melakukan aktifitas sex lebih dari atau sama dengan 17 tahun.

Selain dari hasil uji bivariat tersebut diatas, jumlah total antara wanita yang melakukan aktifitas sex pertama sebelum umur 17 tahun dan setelah berumur 17 tahun sangat jauh berbeda dimana wanita yang melakukan aktifitas sex pertama sebelum berumur 17 tahun sebanyak $15,5 \%$ sedangkan kelompok wanita yang melakukan aktifitas sex setelah berumur 17 tahun sebanyak $88,8 \%$.

Disamping hasil uji bivariat dan perbandingan total aktifitas sex pertama dilakukan oleh sampel, data yang diperoleh sangatlah terbatas. Data sekunder yang didapatkan sudah berupa data kategori yang berupa jawaban ya dan tidak, bukan berupa data yang lebih rinci seperti pada umur berapa aktifitas itu dilakukan, bagaimana frekuensinya.

Hasil penelitian ini berbeda dengan penelitian Martyn Plummer yang mengamati hubungan sex pertama dengan membagi dalam 3 kelompok kanker terpisah pada wanita berusia $<35$, 35-49 dan $\geq 50$ tahun dengan hasil bahwa risiko terjadinya kanker servik dengan metode kankerse control dimana didapatkan kesimpulan bahwa wanita yang melakukan hubungan sex lebih muda 1,95 kali berisiko terkena kanker servik.

Beberapa hal yang membuat penelitian ini berbeda dimungkinkan karena pemeriksa dalam menanyakan hubungan sex pertama merasa tidak etis seperti yang di sampaikan oleh seorang bidan pemeriksa

"Untuk menanyakan tentang hubungan sex yang pernah dilakukan rasanya kok tidak enak, karena saya rasa akan menyinggung perasaaan orang yang ditanya. Karena itu merupakan rahasia pribadi seseorang yang menyangkut moral etika, paling yang saya tanyakan kapan menikah atau sebelum menikah apakah sudah hamil dulu".

Faktor risiko yang tidak terbukti berhubungan kanker analisis multivariat terjadinya lesi servik di Kabupaten Wonosobo

a. Jumlah Pasangan WUS lebih dari satu. 
Berdasarkan hasil analisis statistik bivariat dengan menggunakan chi square didapatkan nilai $p=0,870$ dengan $\mathrm{RP}=1,055(\mathrm{Cl} 95 \%$ dengan rentang nilai 0,553-2,014). Artinya ada tidak ada hubungan yang bermakna antara jumlah pasangan WUS dengan kejadian lesi servik. Jadi jumlah pasangan WUS bukan merupakan faktor risiko terjadinya lesi servik di Kabupaten Wonosobo.

Dalam penelitian ini yang dilihat hanyalah dari jumlah pernikahan yang disahkan oleh hukum berbeda dengan pengertian jumlah pasangan seksual yang selalu berganti dengan frekwensi yang lebih sering. Wanita dengan aktivitas seksual yang tinggi, dan sering berganti-ganti pasangan. Berganti-ganti pasangan akan memungkinkan tertularnya penyakit kelamin, salah satunya Human Papilloma Virus (HPV). Virus ini akan mengubah sel-sel di permukaan mukosa hingga membelah menjadi lebih banyak sehingga tidak terkendali sehingga menjadi kanker. ${ }^{28-30}$

Hal ini juga sesuai dengan indepth interview yang dilakukan pada saat penelitian antara lain sebagai berikut

"Dalam pengkajian yang disebut pasangan adalah pernikahan yang dilakukan menurut hukum bukan pasangan dalam melakukan aktifitas seksual. Karena untuk menanyakan seperti itu saya tidak berani karena akan menyinggung perasaaan pasien, disamping itu kadang kadang pasien diminta untuk mengisi sendiri anamnesa seperti umur, jumlah anak dan sebagainya selain pemeriksaan fisik"

b. Paritas WUS lebih dari 1

Berdasarkan hasil analisis uninavariat WUS dengan paritas lebih dari 1 yang mengalami lesi servik hampir sepertiga dari WUS dengan paritas kurang dari 1 namun uji statistik bivariat dengan menggunakan chi square didapatkan nilai $p=0,649$ dengan $\mathrm{RP}=0.921$ ( $\mathrm{Cl} 95 \%$ dengan rentang nilai $0.648-1.311$. Artinya tidak ada hubungan yang bermakna antara Paritas WUS dengan kejadian lesi servik. Jadi jumlah paritas WUS bukan merupakan faktor risiko terjadinya lesi servik di Kabupaten Wonosobo.

Hasil penelitian ini berbeda dengan penelitian yang dilakukan oleh Nubia Munos; Kami menemukan hubungan langsung antara jumlah kehamilan jangka penuh dan risiko kanker sel skuamosa: rasio odds untuk tujuh kehamilan jangka penuh atau lebih itu $3,8 \quad(95 \% \quad \mathrm{Cl} \quad 2,7-5,5)$ dibandingkan dengan nulipara perempuan, dan 2,3 (1,6-3-2) dibandingkan dengan perempuan yang memiliki satu atau dua kehamilan cukup bulan. ${ }^{31}$

Semakin tinggi risiko pada wanita dengan banyak anak, apalagi dengan jarak persalinan yang terlalu pendek. Dari berbagai literatur yang ada, seorang perempuan yang sering melahirkan (banyak anak) termasuk golongan risiko tinggi untuk terkena penyakit kanker leher rahim. Dengan seringnya seorang ibu melahirkan, maka akan berdampak pada seringnya terjadi perlukaan di organ reproduksinya yang akhirnya dampak dari luka tersebut akan memudahkan timbulnya Human Papilloma Virus (HPV) sebagai penyebab terjadinya penyakit kanker leher rahim.

Disisi lain dalam pengkajian yang dilakukan oleh pemeriksa tidak menanyakan berapa jarak kelahiran antara anak satu dengan yang lain bahkan beberapa pasien mengisi 
status jumlah kelahiran sendiri sepert yang diperoleh dalam indepth interview

"untuk data seperti umur, jumlah anak, jumlah perkawinan kadang sering pasien sendiri yang menulis sebelum diperiksa"

c. Umur Menstruasi kurang dari 12 tahun

Berdasarkan hasil analisis statistik bivariat dengan menggunakan chi square didapatkan nilai $\mathrm{p}=0,049$ dengan $\mathrm{RP}=0.530(\mathrm{Cl} 95 \%$ dengan rentang nilai $0.275-1.021)$. Artinya tidak ada hubungan yang bermakna antara umur pertama menstruasi WUS dengan kejadian lesi servik. Jadi Umur menstruasi dibawah 12 tahun bukan merupakan faktor risiko terjadinya lesi servik di Kabupaten Wonosobo.

Usia menarche dipengaruhi oleh status gizi seseorang. Status gizi perlu diperhatikan karena status gizi yang kurang dapat mengakibatkan menstruasi lebih lambat dari yang seharusnya. Hal ini dikemukakan oleh Riyadi yaitu remaja putri yang bergizi baik mempunyai kecepatan pertumbuhan yang lebih tinggi pada masa sebelum pubertas (prapubertas) dibandingkan dengan remaja yang kurang gizi ${ }^{32}$. Remaja kurang gizi ini tumbuh lebih lambat untuk waktu yang lebih lama, karena itu menarche (umur pertama kali mendapat menstruasi) juga tertunda. ${ }^{33}$

Pada beberapa situasi, perbedaan sosial atau ekonomi mencerminkan perbedaan etnik atau genetik. Menurunnya umur rata-rata saat menarche terlihat pada beberapa populasi dan perubahan sekular menandakan adanya perbaikan faktorfaktor yang berhubungan dengan kesehatan sehingga memungkinkan terjadinya kematangan (maturation) yang lebih cepat pada saat remaja ${ }^{34}$ d. Merokok dan Paparan Asap Rokok lebih dari 1 jam per hari

Berdasarkan hasil analisis statistik bivariat dengan merokok menggunakan chi square didapatkan nilai $p=0,519$ dengan $R P=1.268(C l$ $95 \%$ dengan rentang nilai 0.620 2.593). sedangkan untuk paparan asapa rokok lebih dari 1 jam per hari didapatkan nilai $p=0,587$ dengan $\mathrm{RP}$ $=1.091(\mathrm{Cl} 95 \%$ dengan rentang nilai 0.796 - 1.496). Artinya tidak ada hubungan yang bermakna antara merokok, paparan asap rokok lebih dari 1jam perhari terhadap kejadian lesi servik. Jadi kebiasaan merokok dan paparan asapa rokok lebih dari 1 jam per hari pada WUS tidak terbukti sebagi faktor risiko terjadinya lesi servik di Kabupaten Wonosobo.

Beberapa mekanisme molekuler telah diyakini bahwa merokok dapat berkontribusi karsinogenesis serviks: dengan melibatkan paparan langsung dari asam deoksiribonukleat (DNA) dalam sel-sel epitel serviks nikotin dan cotinine, dan yang lainnya melibatkan paparan produk metabolisme yang dihasilkan dari reaksi komponen lainnya rokok seperti hidrokarbon polisiklik aromatik dan amina aromatik. ${ }^{35-36}$ lendir serviks perokok mengandung sejumlah konstituen rokok dan metabolitnya seperti benzo [a] pyrene $(B A P)^{37}$, nikotin, dan nikotin yang berasal nitrosamin 4(methylnitrosamino) - 1- (3-pyridyl) -1butanone. ${ }^{38}$ BAP dapat meningkatkan kemungkinan integrasi DNA virus ke dalam genom inang, dalam perkembangan kanker serviks. ${ }^{39}$ Efek in vivo paparan nikotin jangka panjang dapat mempengaruhi proliferasi seluler, penghambatan apoptosis, dan stimulasi faktor pertumbuhan endotel 
vaskular, dengan peningkatan

kepadatan pembuluh darah mikro. ${ }^{40}$

mekanisme lain yang dapat menjelaskan merokok terkait karsinogenesis terkait dengan kelainan pada sistem kekebalan sistemik dan perifer perokok, yang menkankerkup produksi sistemik tidak seimbang dari pro dan anti inflamasi sitokin, ${ }^{41}$ peningkatan jumlah limfosit sitotoksik / penekan $T$ limfosit, penekanan aktivitas $T$ limfosit, berkurangnya limfosit $T$ helper, penurunan jumlah limfosit pembunuh alami dan rendahnya tingkat imunoglobulin selain imunoglobulin $\mathrm{E} \quad(\lg \mathrm{E}){ }^{42}$ Efek ini mungkin akibat dari substansial penurunan jumlah sel Langerhans pada serviks perokok. ${ }^{43-44}$ Penyimpangan HPV-induced DNA metilasi mungkin mekanisme lain untuk menjelaskan karsinogenesis serviks yang berhubungan dengan merokok. Dalam studi vitro di baris sel untransformed dan diubah menunjukkan bahwa paparan jangka pendek untuk nikotin atau asap rokok ekstrak diikuti oleh perubahan dalam ekspresi DNA. ${ }^{45}$

Wanita perokok lebih berisiko terkena kanker serviks dibandingkan dengan wanita yang tidak merokok. Zat-zat tersebut akan menurunkan daya tahan serviks di samping merupakan ko-karsinogen infeksi virus. $^{46} \quad$ Toksisitas suatu zat ditentukan oleh besarnya paparan (dosis), dan lamanya pemaparan asap rokok. Asap rokok yang dihirup oleh orang yang terpapar mengandung nikotin lebih banyak dari pada orang yang merokok. Dengan kata lain bahwa kadar nikotin yang dilepaskan ke lingkungan lebih banyak dari pada nikotin yang dihisap oleh perokok. Perbandingan jumlah nikotin dalam asap lebih banyak $4-6$ kali dari pada yang terdapat pada si perokok ${ }^{47}$

Hasil penelitian ini sangat berbeda dengan penelitian yang dilakukan oleh Fujita dengan responden sebanyak 2016 dengan metode kankerse control didapatkan Merokok kanker bermakna dikaitkan dengan peningkatan risiko kanker serviks. Sebuah hubungan dosis-respons dengan jumlah rokok per hari juga diamati ( $p$ untuk trend $=$ 0.004). ${ }^{48}$ Lebih jauh penelitian Chaturvedi, A.K., R.A. Kleinerman, et al. menyampaikan bahwa penderita kanker karena infeksi HPV akan semakin signifikan beresiko 2,07 kali lipat pada pengguna rokok. ${ }^{49}$

Pada penelitian ini data yang digunakan berupa data sekunder. awal dari responden merokok dan lamanya paparan asap rokok tidak diketahui kanker rinci tidak seperti pada pennelitian yang menggunakan kankerse control, sehingga efek dari merokok dan paparan asap rokok tidak terbukti.

e. Riwayat Penggunaan KB Hormonal lebih dari 5 tahun

Penggunaan kontrasepsi oral yang dipakai dalam jangka lama yaitu lebih dari 4 tahun dapat meningkatkan risiko kanker leher rahim 1,5-2,5 kali. Kontrasepsi oral mungkin dapat meningkatkan risiko kanker leher rahim karena jaringan leher rahim merupakan salah satu sasaran yang disukai oleh hormon steroid perempuan. Hingga tahun 2004, telah dilakukan studi epidemiologis tentang hubungan antara kanker leher rahim dan penggunaan kontrasepsi oral. Meskipun demikian, efek penggunaan kontrasepsi oral terhadap risiko kanker leher rahim masih kontroversional

Endometrium adalah salah satu jaringan yang paling hormonal 


JURNAL KEBIDANAN
responsif dalam tubuh dan
menyimpang paparan hormon dapat
menyebabkan perubahan neoplastik,
termasuk hiperplasia dan
adenokarsinoma.
endometrium dan adenokarsinoma
timbul dari kelenjar endometrium dan
menunjukkan perbedaan histologis
yang berbeda dibandingkan dengan
endometrium Wanita dengan
hiperplasia kompleks dengan atypia
memiliki risiko terbesar terkena
kanker $^{50}$

SIMPULAN

Faktor-faktor yang terbukti statistik multivariat dengan $\mathrm{Cl}$ 95\% yang merupakan faktor risiko terjadinya lesi servik pada WUS di Kabupaten Wonosobo adalah:

a. Ada hubungan yang bermakna kanker statistik antara riwayat kanker pada keluarga dengan lesi servik. Riwayat kanker pada keluarga mempunyai risiko 1.831 kali terjadi lesi

\section{DAFTAR PUSTAKA}

$\begin{array}{lr}\text { Adekunle O. } & \text { Cervikankerl } \\ \text { Intraepithelial } & \text { Neoplasia } \\ \text { (CIN)(Squamous } & \text { Dysplasia). } \\ \text { 2010:279-302. } & \end{array}$

Iskandar TM. Pengelolaan Lesi Prakanker Serviks. Indonesian Journal of Kankerncer. 2009;3(3):97-102.

Ehrlich SD. Cervikankerl dysplasia 2013.

RI D. PetunjukTeknisPencegahan DeteksiDiniKankerLeher Rahim dan Kanker Payudara. Jakarta: Departemen Kesehatan Rl; 2008.

Departemen KR. Pedoman Teknis Pengendalian Kanker Payudara dan
April $2017 \quad$ ISSN.2089-7669

servik bila dibandingkan WUS yang tidak mempunyai riwayat kanker pada keluarga.

b. Usia WUS dan Usia pertama melakukan aktifitas sex merupakan faktor risiko protektif dimana untuk $\mathrm{Cl}$ 95\% interval pada angka 1.

Faktor-faktor yang tidak terbukti kanker statistik multivariat adalah : jumlah pasangan, paritas, umur pertama menstruasi, merokok, paparan asap rokok dan riwayat penggunaan KB hormonal

\section{SARAN}

Wanita usia subur lebih sering melakukan pemeriksaan IVA terutama bila ada anggota keluarga yang memiliki riwayat penyakit kanker atau tumor

Bagi Dinas kesehatan lebih mengintensifkan promosi IVA bagi Wanita usia subur

Kanker Leher Rahim. Jakarta: Dep.Kes.RI; 2010.

WHO. Cervikankerl Kankerncer Screening In Developing Countries Genewa: WHO; 2002.

Tierney B, Early Cervikankerl Neoplasia: Advances in Screening and Treatment Modalities. $\mathrm{NIH}$ Public Access. 2010;8(8):547-555.

Rasjidi I. Epidemiologi Kanker Serviks. Indonesian Journal of Kankerncer. Juli 2009;3(3).

PemKab.Wonosobo. Potensi Daerah. 2012.

Dinas KKW. Profil Kesehatan Kabupaten Wonosobo. Wonosobo2013. 
Kementerian.KesehatanRI. Pusat Informasi Kementrian Kesehatan RI: Stop Kanker. 2014.

DinKes.Prop.Jateng. Profil Kesehatan Propinsi Jawa Tengah. semarang: Kesehatan Propinsi Jawa Tengah; 2013.

Notoatmodjo S. Metodologi Penelitian Kesehatan. Jakarta: Rineka Cipta; 2003.

.Lindor NM, Greene MH. The Concise Handbook of Family Kankerncer Syndromes. Journal of the National Kankerncer Institute. 1998;90(14).

Zoodsma M, Sijmons RH, Vries EGEd, Zee AGJvd. Familial Cervikankerl Kankerncer: Kankerse Reports, Review and Clinikankerl Implikankertions. Hereditary Kankerncer in Clinikankerl Practice. 2004;2(2):99-105.

.Jenne DE, Reomann $\mathrm{H}$, Nezu J-i, et al. Peutz-Jeghers syndrome is kankerused by mutations in a novel serine threoninekinase. Nature Genetics. 1998;18:38-43.

Rebeckanker N, Sweet K, En C. Highly penetrant hereditary kankerncer syndromes. Nature Publishing Group. 2004;23:6445-6470.

Burk RD, Chen Z, Doorslaer KV. Human Papillomaviruses:Genetic Basis of Kankerrcinogenicity. Public Health Genomics. 2009;12:281-290.

Kankerstle PE, Jeronimo J, Schiffman $\mathrm{M}$, et al. Age-Related Changes of the Cervix Influence Human Papillomavirus Type Distribution. The Journal of Kankerncer Research. 2006;66(2):1218-1224.
Makuza JD, Nsanzimana S, Muhimpundu MA, Pace LE, Ntaganira J, Riedel DJ. Prevalence and risk factors for cervikankerl kankerncer and pre-kankerncerous lesions in Rwanda. panafrikankernmed-journal. 2015.

Alejandra C, Landy R, Cuzick J, Sasieni P. Cervikankerl Screening at Age 50-64 Years and the Risk of Cervikankerl Kankerncer at Age 65 Years and Older: Population-Based Kankerse Control Study. PLOS Medicine. 2014;11(1).

Moscicki A, Winkler B, CE JI, Schachter J. Differences in biologic maturation, sexual behavior, and sexually transmitted disease between adolescents with and without cervikankerl intraepithelial neoplasia. $J$ Pediatric. 2009;115:487-493.

Elson D, Riley R, Lacey A, Thordarson G, Talamantes F, Arbeit J. Sensitivity of the cervikankerl transformation zone to estrogeninduced squamous kankerrcinogenesis. Kankerncer Res. 2000;60:1267-1275.

Singer A, Monaghan J. Colposcopy of the Normal Cervix: A Prerequisite to Establish the Diagnosis of Cervikankerl Prekankerncer. Lower Genital Tract Prekankerncer: Colposcopy, Pathology and Treatment. Vol 4. UK: Blackwell Sciences Ltd; 2008.

Rasjidi I, Irwanto Y, Wikankerksono B. Modalitas Deteksi Dini Kanker Serviks. Vol I. Jakarta: Sagung Seto; 2009. 
Rasjidi I. Deteksi Dini dan Pencegahan Kanker Pada Wanita. Jakarta: CV Sagung Seto; 2006.

Bustan MN. Epidemiologi Penyakit Tidak Menular. Jakarta: Rineka Cipta; 2007.

Shepherd J, Peersman G, Weston R, Napuli I. Cervikankerl kankerncer and sexual lifestyle: a systematic review of health edukankertion interventions targeted at women. Oxford Journals. 2010;15(6):681694.

Saslow D, Solomon D, HW L, et al. Amerikankern Kankerncer Society, Amerikankern Society for Colposcopy and Cervikankerl Pathology, and Amerikankern Society for Clinikankerl Pathology screening guidelines for the prevention and early detection of cervikankerl kankerncer. US National Library of Medicine National Institutes of Health. 2012;63(3).

Greenwald HP, McCorkle R. Sexuality and Sexual Function in Long-Term Survivors of Cervikankerl Kankerncer. JOURNAL OF WOMEN'S HEALTH. 2008;17(6).

Nubia DM, MDcorrespondenceemail, MD SF, et al. Role of parity and human papillomavirus in cervikankerl kankerncer: the IARC multicentric kankerse-control study. the Lancet. 2002;339(9312):10931101.

Riyadi H. Metode Penilaian Status Gizi kanker Antropometri. Bogor: IPB Press.; 2003.

Amaliah N, Sari K, Rosha BC. Status tinggi badan pendek berisiko keterlambatan usia menarche. Penel Gizi Makan 2012;35(2):150158.

Riyadi H. Gizi dan Kesehatan dalam Pembangunan Pertanian. Bogor: IPB Press; 2006.

Simons AM, Phillips DH, Coleman DV. Damage to DNA in cervikankerl epithelium related to smoking tobacco. British Medikankerl Journal. 2003;306:1444-1448.

Helberg. Smoking and cervikankerl intraepithelial neoplasia: nicotine and cotinine in serum and cervikankerl mucus in smokers and nonsmokers. Amerikankern Journal of Obstetrics and Gynecology. 2008;158(4):910-913. 